\title{
Hemichorea in 15-year-old patient with poorly controlled type 1 diabetes mellitus
}

\author{
Yong Hyuk Kim*, Ho-Seong Kim \\ From 7th APPES Biennial Scientific Meeting \\ Nusa Dua, Bali. 14-17 November 2012
}

\section{Introduction}

Hemichorea, spontaneous unilateral involuntary movements and contralateral neuroimaging abnormalities of the striatum may be the presenting feature of nonketotic hyperglycemia in older adults with type 2 diabetes, but cases in children with type 1 diabetes are very rare.

\section{Case}

A 15-year-old woman with a 6-year history of type $1 \mathrm{DM}$ developed righthemichorea. She presented continuous involuntary choreic movements of both herright arm and leg. The movements were nonsuppressible and ceased only during sleep.With the exception of this movement disorder, other neurological examination was unremarkable. On funduscopic examination, nonproliperative diabetic retinopathy was detected. The following laboratory findings were notable: fasting blood glucose $162 \mathrm{mg} / \mathrm{dL}$, serum osmolarity $305 \mathrm{mOsm} / \mathrm{L}$, and $\mathrm{HbA1c} 13.2 \%$. Urinalysis was negative for glucose, ketones, and protein. There were no signs of diabetic ketoacidosis, hypoglycemia, hyperosmolar hyperglycemic coma, or rheumatic fever.Cranial computed tomographic scan showed that hyperattenuation of the left basal ganglia. T1-weighted magnetic resonance image demonstrated that hyperintensity of the left striatum. The hemichorea was slowly controlled with small oral doses of haloperidol $(1.5 \mathrm{mg} / \mathrm{d})$ and intensive blood glucose control.

\section{Conclusion}

We report the case of a 15 -year-old poorly controlled diabetic adolescent girl who developed acute hemichorea of the right arm and leg in whom T1-weighted magnetic resonance imaging of the brain revealed hyperintense signal in left basal ganglia.

\section{Department of Pediatrics, College of Medicine, Yonsei University, Seoul,} Korea

(C) 2013 Kim and Kim; licensee BioMed Central Ltd. This is an Open Access article distributed under the terms of the Creative Commons Attribution License (http://creativecommons.org/licenses/by/2.0), which permits unrestricted use, distribution, and reproduction in any medium, provided the original work is properly cited.
doi:10.1186/1687-9856-2013-S1-P17

Cite this article as: Kim and Kim: Hemichorea in 15-year-old patient with poorly controlled type 1 diabetes mellitus. International Journal of Pediatric Endocrinology 2013 2013(Suppl 1):P17.
Submit your next manuscript to BioMed Central and take full advantage of:

- Convenient online submission

- Thorough peer review

- No space constraints or color figure charges

- Immediate publication on acceptance

- Inclusion in PubMed, CAS, Scopus and Google Scholar

- Research which is freely available for redistribution Submit your manuscript at
www.biomedcentral.com/submit C Biomed Central 